\title{
International Experts' Influence on Company Internationalization
}

\author{
Grygorii Kravchenko ${ }^{1}$
}

Submitted: 11.06.2021. Accepted: 4.11.2021

\section{Abstract}

Purpose: The article evaluates the associative relationship between international supervisory board experts and foreign ownership, along with the experts' influence on the financial and operating performance of firms. The study was based on data collected for 257 companies listed on the Warsaw Stock Exchange in 2010-2015.

Methodology: The dataset was built as a panel, and then generalized least squares regression models with a fixed or random effect were employed to test hypotheses.

Findings: The findings of the study clearly show that the presence of investigated firms in foreign markets positively affects company performance. Moreover, models with dependent variables ROA and ROS show that supervisory board members with foreign experience positively affect profitability indicators of firms that do not operate on foreign markets. The data analyses reveal that international experts are more effective advisors for companies that conduct no business activities on foreign markets. Furthermore, the results show a positive moderate association between the share of international experts in supervisory boards and the share of foreign ownership in the company.

Originality: The article contributes to the understanding of determinants and consequences of the presence of international experts in supervisory boards and company internationalization.

Keywords: international experts, company internationalization, foreign ownership, firm financial and operating performance.

JEL: G30, M14, M41

1 Kozminski University, 59 Jagiellonska St., 03-301 Warsaw; e-mail: gkravchenko@kozminski.edu.pl; https://orcid.org/0000-0001-5269-6300. 


\section{Introduction}

In recent years, corporate governance is a very popular topic (Słomka-Gołębiewska and Urbanek, 2016; Dobija and Kravchenko, 2017; García-Sánchez et al., 2018; Joh et al., 2018; Kumar et al., 2018; Shin et al., 2018; Goergen and Tonks, 2019; Guest, 2019; Dobija and Puławska, 2021), especially in advanced emerging markets where corporate governance failures costs are excessively high. Undoubtedly, for such countries as Poland - which is the largest and most developed economy in Central and Eastern Europe (CEE) - the necessity to compete for foreign investors from other established markets is extremely significant.

In the early 1990s, the Polish corporate governance and economic system transitioned to the capital market, which mostly affected large companies, as the process implemented previously unknown corporate policies. The first step of the transition started when the necessity of the supervisory board (SB) creation was instituted. As the privatization process began, the government encountered difficulties to find new, professional, and financially stable owners with long-term perspectives who would run businesses properly. This process hindered lawmakers and companies in the adaptation to the new requirements. However, the Polish government later implemented laws protecting the market and investors, especially in the form of a limit of $33 \%$ on the ownership of privatized company shares by national investment funds (Grosfeld and Hashi, 2007). The next step was to transform state-owned entities into companies that had to conduct first general meetings with their shareholders and vote for supervisory boards. Two to three supervisory board members were selected by employees, while the rest of three to four members were selected by State Treasury (Mortimer, 2009).

Recently, Poland had to fulfill the criteria for the higher quality capital market and regulatory environment to become noticed on the global market. In the last years, the Polish corporate governance system did not incorporate the protective measures for smaller shareholders, so among the requirements to be fulfilled, Poland had to establish and bring into action regulations to the recognition and observance of minority shareholders' rights. Furthermore, in the pool of other criteria, the Polish market authorities had to countermand the operation of foreign ownership restrictions and facilitate the foreign investor registration process. Buzavaite and Korsakiene (2019), Chen et al. (2017), Duque-Grisales et al. (2020), González (2019), and Yarbrough et al. (2017) notice that human capital plays an important role in the internationalization and international activities of companies that require appropriate competencies and resources. 
Poland is a member of the EU with no restrictions for intra-EU labor flows. The interest in having international representatives on supervisory boards of multinational businesses is motivated by the idea that foreign experts lead to company internationalization. Consequently, the determinants of a company's success in foreign markets are an interesting research area.

The study described below was aimed to evaluate the associative relationship between international supervisory board experts and foreign ownership, but also their impact on firm financial and operating performance. This research was conducted to look for the appropriate up-to-date answers to the following empirical questions: are international experts more effective advisors in firms that operate on foreign markets? Is there a link between foreign ownership and the share of international supervisory board experts? Does foreign ownership significantly affect firm performance?

The study concentrated on the period when the Polish capital market was classified as an advanced emerging market, when Poland's economic condition was characterized as a constantly developing internationalization process, and when the issue of demographic differentiation of boards was treated as a critical factor for corporate success (Koładkiewicz, 2008). To introduce hypothesis tests, it was compiled a comprehensive panel data-set covering 356 public companies listed on the Warsaw Stock Exchange (WSE) and employed generalized least squares (GLS) regression models with a fixed or random effect.

The findings showed that with the increase in the share of international experts in supervisory boards, the financial performance improves among companies that do not operate in foreign markets. The study confirmed the positive moderate association between the supervisory board nationality diversity and the shareholder heterogeneity. Moreover, the results showed that the higher the share of foreign ownership, the better the financial performance of the company.

The novelty of the article stems from its contribution to the understanding of determinants and consequences of international experts' presence on supervisory boards and company internationalization.

The structure of this article is organized as follows. The next section will present the literature review and hypothesis development. Then, the research design, empirical findings, and robustness check will be presented. The last section will provide a discussion and conclusions of the study. 


\section{Literature Review and Hypothesis Development}

To address the role of supervisory board members in the corporate strategic decisions regarding foreign market operations and others, it needs to refresh supervisory board (SB) functionalities. Peij et al. (2012) argue that supervisory boards are built of non-executive directors to ensure independence from the management team. Supervisory board members are obliged to provide executive directors with supervision and advice, especially when it comes to strategic orientation. The SB also monitors top executives with, first, making decisions regarding their employment, and then their assessment and dismissal (Adams et al., 2010). The literature also often uses the agency and resource dependence theories as a lens for the deeper understanding of SB operations. Adams et al. (2010) argue that SB composition depends on the decisions the economic actors take in response to external environmental conditions. Hillman et al. (2009) claim SB composition results from the rational organization response to the external environment situation. In this vein, firm environment changes caused by multinational operations also result in changes in SB composition. Overall, company internationalization requires the adaptation of specific SB characteristics (Wang et al., 2019) and a broadscope management accounting system that improves company performance by providing necessary information about market competitors and customers (Ngo, 2021).

Hooghiemstra et al. (2019) claim that the SB is a mechanism that operates to ensure the management takes decisions according to the stakeholder interests. With the ability to be part of a decision-making process, SBs affect organizational actions so that they are taken as a determinant of organizational performance. Fama and Jensen (1983) state that SBs comply with the effective monitoring of management, depending on their composition. Soliman and Ragab (2013) note that the substantial number of non-executive directors dedicated to monitoring managers may increase alertness to agency problems. Several studies investigate the effect of SB composition in terms of its diversity on the level of earnings management to find that the number of outside and independent board members is negatively associated with the occurrence of fabricated financial statements, discretionary accounting accruals, and other earnings manipulative techniques (Park and Shin, 2004; Peasnell et al., 2005).

The above idea finds support in Sanders and Carpenter (1998), who claim the operation internationalization causes information asymmetry issues between the SB and managers, which results in higher monitoring costs. They argue that international operations increase managerial complexity and environmental uncertainty, which in turn are associated with information processing demands. Consequently, there occurs the necessity for coordination of resources from different cultural competitive environments. 
Thus, to overcome the demands and changes associated with the internationalization of company operations with the liability of being foreign, there is a need to create efficient governance.

Considering the international experts in the role of resource provision, one may assume that directors bring important resources to the company that operates in foreign markets, such as relevant information and knowledge from the international environment. Nielsen and Nielsen (2013) provide a consistent argument that multinational teams bring different perspectives on the institutional environment. Moreover, national diversity allows for engaging in-depth group discussion and considering a wide range of alternatives, therefore generating creative ideas (Hambrick et al., 1998). The authors conclusively state that multinational teams generate more innovative solutions while being more effective in solving complex tasks. Considering international experts from the strategic perspective, Watson et al. (1993) propose the idea that multinational groups improve the quality and comprehensiveness of top management team strategic decisions. Consequently, the presence of international experts brings a variety of advantages, particularly adding value to the company and improving productivity together with profitability (Giannetti et al., 2012). Moreover, Giannetti et al. (2015) found in the Chinese capital market and documented that firm performance increases after hiring directors with international experience.

Ramaswamy (2001) states that the presence of foreign members on the board may be an indicator of expansion plans, particularly cross-board expansion. Moreover, Zainal et al. (2013) show that the presence of international experts may improve strategic decision-making and corporate governance quality. The authors refer to Veen and Elbertsen (2008), who states that, generally, large firms are multinational companies that are more likely to appoint foreign board members. An increase in the share of international experts is very often a tool for a firm to indicate the ability to understand and deal with challenges faced in the complex nature of company operations (Goodstein et al., 1994; Wiersema and Bantel, 1992).

International SB members can be a source of valuable knowledge about employees with international experience, foreign suppliers, and customers, along with foreign networks, all of which can help to gain important network ties. As a consequence, the employment of international experts may open new business opportunities and better investment and operating decisions. The SB members with an international background who hold specific tacit knowledge - which is difficult to substitute or imitate - are often appointed to create an attractive feature of the companies that seek such tacit knowledge (Barroso et al., 2011). 
Considering the arguments presented above, one may argue that supervisory board members with international experience are proximate to foreign markets and better understand the international business environment. Thus, international experts can better contribute to monitoring and advisory functions of supervisory boards than local experts. Taking into account that international experts increase the efficiency of advisory role performance (Afzali et al., 2020) and play an indicative role in the firm global actions (Ramaswamy, 2001), the following hypothesis was proposed:

H1: Supervisory board members with international experience are effective advisors for the companies that operate in foreign markets.

By virtue of the financial markets' globalization process, corporations are more often forced to internationalize not only their operations but also sources of financing. Those processes are usually defined as commercial and financial internationalization. Moreover, the literature implies the process of internationalization increases the involvement in international markets (Calof and Beamish, 1995) and the adaptation of firm operations in terms of strategy, structure, and resources to international environments. Therefore, the demand for expertise in successful commercial and financial internationalization of companies only increases. Consequently, the expert stewardship of corporations that rely on foreign sources of financing was expected.

The existing literature presents empirical evidence of the important role of social capital and reliance on personal networks in selecting directors. Kim and Cannella (2008) note that personal networks enhance the social capital, which embodies SB composition. This argument can be conformable to the appointment of foreign supervisory board members by foreign shareholders. The underlying idea is that a foreign shareholder's trustworthiness to foreign SB members is enforced by the perceived similarities that depart from similar demography, shared values, and norms (Levin et al., 2006). Oxelheim and Randøy (2013) mention that owners - specifically foreign owners - often want to appoint board members that represent their interests more forcefully. The presence of foreign experts and home-country-based experts with international experience in SB improves the level of firm accountability in international financial markets, thus facilitating access to foreign capital (Luo, 2005). Moreover, the appointment of an expert who is a citizen of a foreign country in which the company shares are listed may indicate the firm's accountability to the foreign investor base, thus attracting foreign investors (Luo, 2005).

Literature often evaluates foreign ownership contributions from internal and external perspectives. From the perspective of corporate governance internal mechanisms, 
Choi et al. (2007) suggest that foreign investors add value to firm performance through their participation in the board of directors. The study conducted by Oxelheim and Randøy (2003) shows that companies have a higher valuation when they have foreign SB members in contrast to those who do not have such members. The authors explain the inclusion of foreign members in the SB may signal a firm's willingness to improve the monitoring function.

Munisi et al. (2014) note that the literature pays little attention to the ownership structure. Chizema and Kim (2010) claim that there is a positive correlation between the share of foreign owners and outside board members. Estélyi and Nisar (2016) present results that indicate a positive and significant association between board nationality diversity and shareholder heterogeneity. Foreign SB members or SB members with international experience may also know the regulatory frameworks and institutions of the foreign company of firm operations and investors (Oxelheim and Randøy, 2003). Thus, it was assumed that there is a positive association between foreign ownership concentration and the share of foreign supervisory board members.

H2: There is a positive associative relationship between foreign ownership concentration and the share of international experts.

Finance literature divides corporate governance mechanisms into internal and external ones (Cuervo, 2002). Among other things, the latter suggests that the market for corporate control and institutional investors affect corporate management monitoring function (Choi et al., 2007). This can be achieved with the help of controlling insiders, such as independent directors, thus contributing to firm performance. Choi et al. (2007) note that the concentrated foreign ownership assists in mitigating the "managerial opportunism and exploitation of atomistic investors." Hence, foreign ownership improves the overall functioning of the corporate governance system and - consequently - firm performance.

Therefore, one may argue that international SB experts can play an indicative role for the firm to bias internationalization. Owing to outsiders' uniqueness determined by the knowledge of a foreign market and its potential, the firm signals to the market about potential expansion actions (Ramaswamy, 2001). Giannetti et al. (2012) present a consistent argument saying that foreign director participation sends a signal to the market that a company seeks international expansion. The authors explain that the firms that have a potential for global expansion, want to attract international experts to the governance structure by informing the market that the firm seeks to internationalize its operations. From another perspective, the authors suggest that having 
foreign representatives on an SB enables external financing through foreign investor engagement.

In turn, Gurbuz and Aybars (2010) show that the level of foreign ownership concentration matters when evaluating its impact on firm performance. The authors find that the minority of foreign-owned companies perform better than domestically-owned and the majority of foreign-owned ones. Moreover, their results show that the majority of foreign-owned companies have the worst performance of all. Thus, it was estimated that foreign ownership positively affects firm performance.

H3: Foreign ownership enhances firm financial and operating performance.

\section{Research Design}

The quantitative research method is used to test the hypothesis, obtain results and provide conclusions for the association between variables. The sample used in the study consisted of 356 companies listed on the WSE in 2010-2015. The raw database was reduced to 257 firms. Only entities that existed during the entire period of observation were included in the final research sample. The investigation was conducted with the use of STATA software.

For the current study 1542 annual reports were analyzed, which were collected from the official investor relations sections of corporate websites. To encode individual supervisory board member-level qualitative characteristics, approximately 7700 members' résumés were reviewed.

\section{Variables}

This section will introduce dependent, independent, and control variables used in the study to analyze and justify the link between theory and practice. The set of variables was chosen based on the existing literature filled with corporate governance and its relation to company performance. The description, measurement, and justification of variables' selection will be presented below. 


\section{Dependent Variables}

\section{Return on Assets}

Return on assets (ROA) is an accounting-based financial performance measure that presents the relationship between net income and total assets owned by a company.

$$
\text { Return on Assets }=\frac{\text { Net Profit }}{\text { Total Assets }}
$$

The ratio assesses the efficiency of using company assets to generate income. The prior literature widely analyzes ROA to investigate the effects of SB structure and composition on company financial performance (Boadi and Osarfo, 2019; Imade, 2019; Jakpar et al., 2019; Jentsch, 2019; Abdeljawad and Masri, 2020). Moreover, ROA can indicate the quality of corporate governance in inspiring higher management effectiveness. On the one hand, the prior empirical literature shows a significant relationship between ROA and corporate governance characteristics (Abdullah, 2014; Azutoru et al., 2017). On the other hand, some evidence of no relationship between ROA and corporate governance structure and composition (Adeusi et al., 2013; Abu et al., 2016). Therefore, to investigate ROA as the first dependent variable to evaluate the international experts' impact on listed companies' financial performance in Poland was decided.

\section{Return on Sales}

Return on sales (ROS) is the ratio used to evaluate the share of profits generated from sales. The formula shows the ability of a company to improve the performance of sales and decrease production costs, indicating operating efficiency (Isidro and Sobral, 2014). Return on sales is useful in determining the management's ability to generate a return on specific volumes of sales.

$$
\text { Return on Sales }=\frac{\text { Net Profit }}{\text { Total Sales }}
$$

Notably, managers are usually forced to seek any growth opportunity - even through less-profitable sales channels - which most often results in the gradual decline of ROS. The ratio can also be useful in industry analysis, enlightening which industry gives the business an opportunity for the most efficient run.

Return on assets and return on sales are actively used empirical tools (Isidro and Sobral, 2014; Knežević et al., 2017; Dedunu and Anuradha, 2020) in the context of corporate governance effectiveness. Table 1 shows dependent variables: ROA and ROS with their definition and data sources, which are used in a current study similar to the presented literature. 
Table 1. Dependent variables

\begin{tabular}{|c|c|c|c|c|c|}
\hline $\begin{array}{l}\text { Study } \\
\text { Issue }\end{array}$ & Variables & Labels & Definition & References & Source \\
\hline 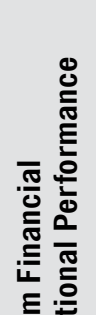 & $\begin{array}{l}\text { Return } \\
\text { on Assets }\end{array}$ & ROA & $\begin{array}{l}\text { Ratio of net } \\
\text { income to } \\
\text { total assets }\end{array}$ & $\begin{array}{l}\text { Abdeljawad and Masri (2020); } \\
\text { Boadi and Osarfo (2019); Imade } \\
\text { (2019); Jakpar et al. (2019); } \\
\text { Jentsch (2019). }\end{array}$ & 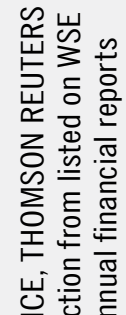 \\
\hline 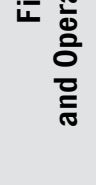 & $\begin{array}{l}\text { Return } \\
\text { on Sales }\end{array}$ & ROS & $\begin{array}{l}\text { Ratio of net } \\
\text { income to } \\
\text { total sales }\end{array}$ & $\begin{array}{l}\text { Dedunu and Anuradha (2020); } \\
\text { Isidro and Sobral (2014); } \\
\text { Knežević et al. (2017). }\end{array}$ & 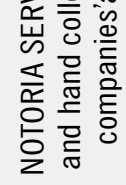 \\
\hline
\end{tabular}

Source: author's own elaboration.

\section{Independent-Explanatory Variables}

The experimental variables used in empirical analysis primarily concern the foreign experience of supervisory board members (EXPERTS). It was distinguished between Polish citizens who disclose prior career track in foreign companies and foreign citizens who disclose experience in companies incorporated in other countries. To avoid duplication or ambiguous labeling, SB positions of non-Polish citizens in Poland were disregarded. The reference group of supervisory board members was Polish citizens without any prior experience in foreign companies. For empirical analysis, a foreign company was identified based on the country of its operation. A company listed on the main market of the Warsaw Stock Exchange but domiciled in another country was regarded as a foreign company. The representation of supervisory board members with diverse experience records at the company level, i.e. the unit of observation underlying econometric analysis was a firm-year aggregated. To ascertain whether a given supervisory board member possessed the foreign experience and could thus be labeled as such in the corporate governance database, it was verified whether incumbent SB members previously served on SBs of foreign companies, particularly checking the industry relatedness of the board member's current and previous company of employment. A supervisory board member was labeled as one having relevant experience if the résumé contained information suggesting that they had previously served as C-suit members - namely as a CEO, CFO, COO, or chief accountant - for a period no shorter than one calendar year. 
To verify the influence of foreign ownership on a company's financial performance, the percentage of ordinary shares held by foreign investors in the observed firm $i$ and time $t$ as the explanatory variable FOROWNER was added (Mangena et al., 2007; Puławska et al., 2021). Moreover, the dummy variable FMO indicating the company that operates on foreign markets was developed to check whether the international experts were more effective advisors for the companies that operate in foreign markets.

Table 2 presents the set of independent variables with their definition, references to studies, and data sources.

Table 2. Explanatory variables

\begin{tabular}{|c|c|c|c|c|}
\hline Variables & Labels & Definition & References & Source \\
\hline $\begin{array}{l}\text { International } \\
\text { experts }\end{array}$ & $\%$ EXPERTS $_{\text {it }}$ & $\begin{array}{l}\text { - The share of international } \\
\text { experts with foreign } \\
\text { experience in the } \\
\text { supervisory board of firm } i \text {, } \\
\text { at time } t \text {. }\end{array}$ & $\begin{array}{l}\text { Frijns et al. (2016); } \\
\text { Masulis, et al. (2012); } \\
\text { Mirza et al. (2020). }\end{array}$ & 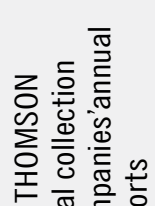 \\
\hline $\begin{array}{l}\text { Foreign } \\
\text { ownership }\end{array}$ & $\%_{F O R O W N E R}$ it & $\begin{array}{l}\text { - The percentage of ordinary } \\
\text { shares held by foreign } \\
\text { investors in an observed } \\
\text { firm } i \text { and time } t \text {. }\end{array}$ & $\begin{array}{l}\text { Mangena et al. } \\
\text { (2007); Puławska et } \\
\text { al. (2018) }\end{array}$ & 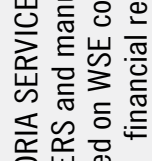 \\
\hline $\begin{array}{l}\text { Foreign } \\
\text { Market } \\
\text { Operation }\end{array}$ & $\mathrm{FMO}_{\text {it }}$ & \multicolumn{2}{|c|}{$\begin{array}{l}\text { The dummy variable that indicates companies } i \text { that } \\
\text { operate in foreign markets at time } t \text {. }\end{array}$} & 을른를 \\
\hline
\end{tabular}

Source: author's own elaboration.

\section{Control Variables}

Considering that the governance-performance relationships should be controlled, this study grouped control variables according to their relation to firm-specific and firm financial performance. The selection of control variables was based on prior studies (Oxelheim and Randøy, 2003; Masulis et al., 2012; Jackowicz et al., 2014; Estélyi and Nisar, 2016; Amin and Nor, 2019; Tapver, 2019; Mehmood et al., 2019; Hossain, 2020; Mirza et al., 2020; Salehi et al., 2020). The inclusion of individual effects was determined by the need to control for individual heterogeneity. The possible macroeconomic factors that could affect the dependent variable were controlled by time dummy variables. As a result of the literature review, Table 3 gathers the following control measures selected for analysis. 
Table 3. Control variables

\begin{tabular}{|c|c|c|c|c|}
\hline Variables & Labels & Definition & References & Source \\
\hline \multicolumn{4}{|c|}{ Firm-related control variables } & \\
\hline Firm age & $\mathrm{AGE}_{\mathrm{it}}$ & $\begin{array}{l}\text { Dummy variable that indicates } \\
\text { the firm } i \text { age at time } t \text { since } \\
\text { was founded and coded as } 1 \text { if } \\
\text { the companies is higher than } \\
\text { median for total sample } \\
\text { (26 years) and } 0 \text { otherwise. }\end{array}$ & $\begin{array}{l}\text { Frijns et al. (2016); } \\
\text { Kaczmarek et al. (2012); } \\
\text { Mehmood et al. (2019). }\end{array}$ & 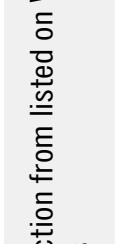 \\
\hline $\begin{array}{l}\text { Type } \\
\text { of industry }\end{array}$ & INDUSTRY $_{\text {it }}$ & $\begin{array}{l}\text { The industry (Service, } \\
\text { Merchandising and } \\
\text { Manufacturing) in which firm } i \text {, } \\
\text { at time } t \text { operates. }\end{array}$ & $\begin{array}{l}\text { Amin and Nor (2019); } \\
\text { Bradbury et al. (2006). }\end{array}$ & 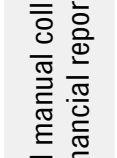 \\
\hline \multicolumn{4}{|c|}{ Firm-financial control variables } & \\
\hline \multirow{2}{*}{$\begin{array}{l}\text { Structure } \\
\text { of Assets }\end{array}$} & $\mathrm{FIXA}_{\text {it }}$ & $\begin{array}{l}\text { Ratio of fixed assets to assets } \\
\text { in a company } i \text { at time } t \text {. }\end{array}$ & $\begin{array}{l}\text { Jackowicz et al. (2014); } \\
\text { Mirza et al. (2020). }\end{array}$ & 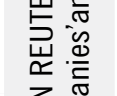 \\
\hline & $\mathrm{REC}_{\text {it }}$ & $\begin{array}{l}\text { Ratio of short-term receivables } \\
\text { to assets in a company } i \\
\text { at time } t \text {. }\end{array}$ & Jackowicz et al. (2014). & $\stackrel{\infty}{\sum_{0}^{\infty}}$ \\
\hline $\begin{array}{l}\text { Financial } \\
\text { leverage }\end{array}$ & $E Q_{i t}$ & $\begin{array}{l}\text { Ratio of equity capital to assets } \\
\text { in a company } i \text { at time } t \text {. }\end{array}$ & $\begin{array}{l}\text { Jackowicz et al. (2014); } \\
\text { Tapver (2019). }\end{array}$ & 点 \\
\hline $\begin{array}{l}\text { Assets } \\
\text { turnover }\end{array}$ & TAT $_{\text {it }}$ & $\begin{array}{l}\text { Ratio of sales to assets } \\
\text { in a company } i \text { at time } t \text {. }\end{array}$ & $\begin{array}{l}\text { Hossain (2020); } \\
\text { Salehi et al. (2020); } \\
\text { Jackowicz et al. (2014). }\end{array}$ & $\begin{array}{l}\overline{\underline{c}} \\
\text { 응 } \\
\text { ㄴ }\end{array}$ \\
\hline
\end{tabular}

Source: author's own elaboration.

\section{Empirical Model}

The study evaluated the relationship between international supervisory board experts and foreign ownership, along with their impact on a firm's financial and operating performance. The dataset was built as a panel, while diagnostic tests like the Pearson's correlation coefficient, the Breusch-Pagan test, the Hausman test, and the Durbin-Watson test were used to examine the appropriateness of linear regression model assumptions that affected the modelling process to identify the extraordinary characteristics of the data that could potentially affect conclusions (Cook and Weisberg, 1983). 
The fixed and random effects models were chosen with the Breusch-Pagan test (Breusch and Pagan, 1979) and the Hausman test (Hausman, 1978). The Breusch-Pagan Lagrangian multiplier test helped to define whether the pooled ordinary least squares (OLS) and random-effects models were best suited for the analysis. Hausman's specification test helped us to identify whether the individual-level effects were adequately constructed and modeled by fixed effects.

The results obtained from the above tests first suggested that the OLS regression model did not fulfill what was expected of the analysis, and second, the generalized least squares (GLS) regression with the fixed or random effect were found to be appropriate to raise the hypothesis tests. According to the Durbin-Watson test, no autocorrelation existed in the fixed and random effects models with dependent variables ROA and ROS. The model was built to incorporate the year's dummy and industry variables to control for possible macroeconomic factors that could affect dependent variables.

Company Performance $(R O A, R O S)_{i t}$

$$
\begin{aligned}
& =\alpha+\beta_{1} \% \text { EXPERTS }_{i t}+\beta_{2} \% \text { FOROWNER }_{i t}+\beta_{3} \text { FMO }_{i t}+\beta_{4} \text { Firm }_{\text {CONTROLS }_{i t}} \\
& +\beta_{5} \text { FirmPerformance }_{\text {CONTROLS }_{i t}}+\psi_{t}+\eta_{i}+\varepsilon
\end{aligned}
$$

in which:

- company performance (ROA, ROS) $)_{\mathrm{it}}$ :

1) $\mathrm{ROA}_{\mathrm{it}}$ - is an accounting-based financial performance measure that presents the relationship between net income and total assets owned by the company;

2) $\mathrm{ROS}_{\mathrm{it}}$ - is the ratio that is used to evaluate the share of profits generated from sales;

- \%EXPERTS ${ }_{\text {it }}$ - the share of international experts with foreign experience in the supervisory board of firm i at time $t$;

- \%FOROWNER ${ }_{\text {it }}$ - the percentage of ordinary shares held by foreign investors in a firm i at time t;

- $\mathrm{FMO}_{\mathrm{it}}$ - the dummy variable that indicates companies i that operate in foreign markets at time t;

- FirmCONTROLS ${ }_{\text {it }}$ - the group of firms related control variables, such as:

1) $\mathrm{AGE}_{\mathrm{it}}$-dummy variable that indicates the firm $i$ age at time $t$ since was founded and coded as 1 if the company age is higher than the median for the total sample (26 years) and zero otherwise;

2) INDUSTRY $_{\text {it }}$ - the industry (service, merchandising, and manufacturing) in which firm i at time toperates;

- FirmPerformanceCONTROLS ${ }_{\mathrm{it}}$ - the group of firm financial control variables, such as: 
1) FIXA $_{\text {it }}$ - the variable that shows the structure of assets, and is calculated as the ratio of fixed assets to assets in a company i at time t;

2) $\mathrm{REC}_{\mathrm{it}}$ - the variable that shows the structure of assets, and is calculated as the ratio of short-term receivables to assets in a company $i$ at time $t$;

3) $\mathrm{EQ}_{\mathrm{it}}$ - the variable that shows the firm financial leverage, and is calculated as the ratio of equity capital to assets in a company i at time t;

4) $\mathrm{TAT}_{\text {it }}$ - the variable that shows the assets turnover, and is calculated as the ratio of sales to assets in a company $i$ at time t;

- i - companies index;

- $t$-time period;

- $\alpha$ - constant;

- $\psi_{t}$ - time effects;

- $\eta_{i}$ - individual effects;

- $\varepsilon$ - the standard error.

\section{Empirical Results}

Table 4 presents the primary analysis of the data in the form of a summary of descriptive statistics. Charts 1-3 offer a summary of the average values for the variables through the entire period 2010-2015 under investigation. The average values for ROA and ROS for the period $2010-2015$ were $3 \%$ and $-6.75 \%$ respectively.

However, to be able to draw precise conclusions regarding the performance of companies that operated on foreign markets and those that did not, Charts 2 and 3 were built to show the change of average values of ROA and ROS through the analyzed period. The mean and median values showed that no outliers were taken for analysis. Such is also the result of winsorization at the $1^{\text {st }}$ and $99^{\text {th }}$ percentile values. Winsorization was applied to the variables due to outlier presence. The level of winsorization remained unchanged for both variables (ROA and ROS) used in the presented analysis.

According to Figure 1, the ROA and ROS trend lines differed significantly for companies that operated on foreign markets. A sharp decrease in ROS performance indicators was observed from 2010 to 2012. The move of average ROS was negative 18.14\%, which indicated some significant factors that could affect a firm's operational efficiency. This dramatic change could be assigned to the issues related to foreign markets, as when comparing the performance of companies that did not have operations abroad in Poland, the average ROS did not change significantly, showing a negative $7.2 \%$ of change from 2010 to 2012. On the other hand, the following period 2012-2015 reveals an 
opposite development. The operating efficiency recovered up to $4.17 \%$ in 2015 among companies with foreign operations, while those without foreign operations experienced an even more dramatic decrease in ROS - down to $28.8 \%$. The ROA in its term did not change much, revealing a comparatively steady move through the investigated period.

\section{Table 4. Summary Statistics}

\begin{tabular}{|l|c|c|c|c|c|}
\hline \multicolumn{1}{|c|}{ Variable } & Mean & Median & S.D. & Min & Max \\
\hline ROA & 0.0300 & 0.0345 & 0.0758 & -0.213 & 0.185 \\
\hline ROS & -0.0674 & 0.0339 & 1.18 & -9.25 & 2.98 \\
\hline EXPERTS & 0.167 & 0.000 & 0.253 & 0.000 & 1.00 \\
\hline FOROWNER & 0.0869 & 0.000 & 0.187 & 0.000 & 0.999 \\
\hline FMO & 0.361 & 0.000 & 0.480 & 0.000 & 1.00 \\
\hline AGE & 0.326 & 0.000 & 0.469 & 0.000 & 1.00 \\
\hline INDUSTRY & 2.14 & 2.00 & 0.858 & 1.00 & 3.00 \\
\hline FIXA & 0.503 & 0.503 & 0.220 & 0.0251 & 0.949 \\
\hline REC & 0.231 & 0.194 & 0.169 & 0.00538 & 0.790 \\
\hline EQ & 0.520 & 0.520 & 0.196 & 0.0568 & 0.940 \\
\hline TAT & 1.09 & 0.969 & 0.849 & 0.0105 & 4.55 \\
\hline
\end{tabular}

Source: author's own elaboration.

Figure 1. ROA \& ROS: Companies Presented on Foreign Markets

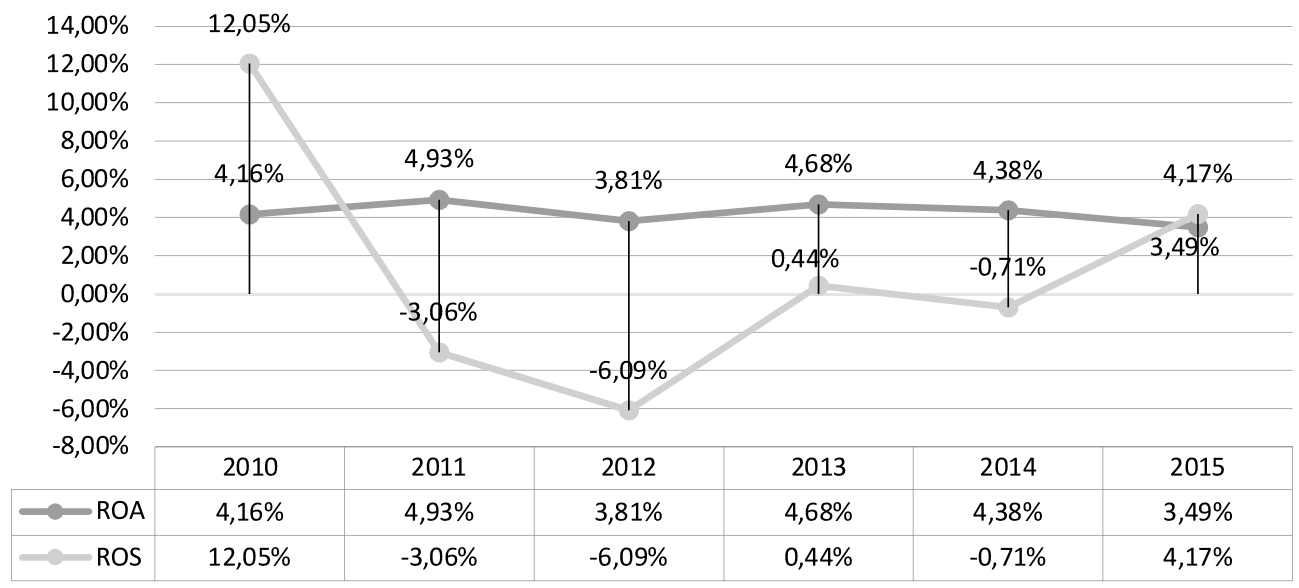

Source: author's own elaboration. 
Figure 2. ROA \& ROS: Companies Not Presented on Foreign Markets

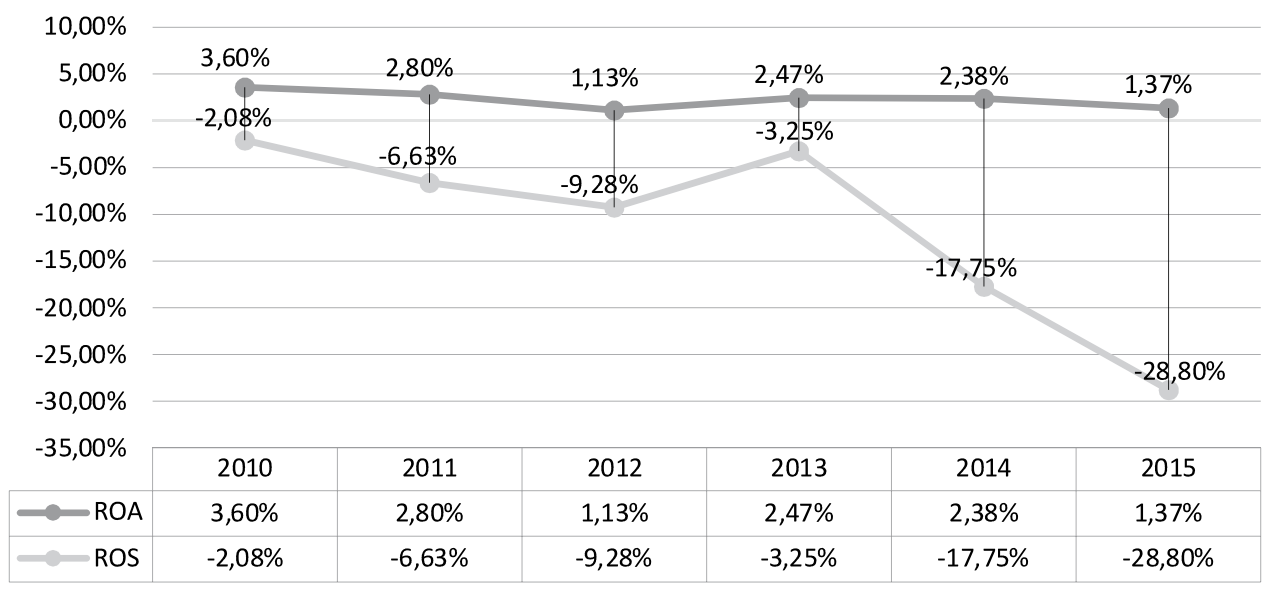

Source: author's own elaboration.

According to Table 4, the average share of foreign ownership was $8.7 \%$ for the entire investigation period. Figure 3 showed that the share of foreign ownership did not change since 2010, suggesting that the structure of firm ownership was not subject to rapid change, and the evaluation of trend lines in this specific case should be based on a longer period.

Figure 3. The Share of International Experts and the Share of Foreign Ownership

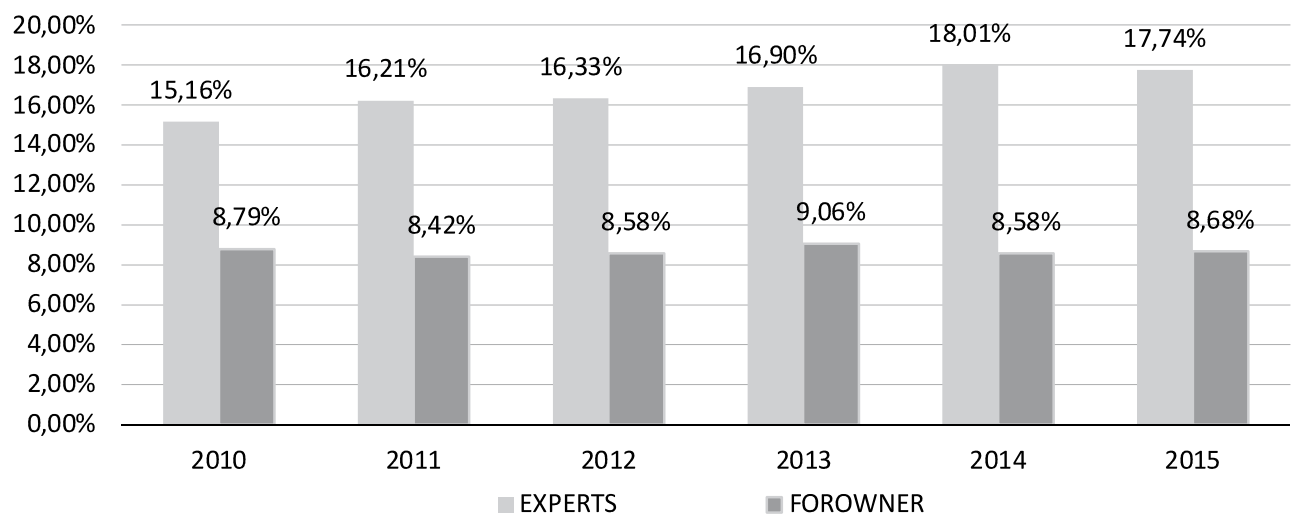

Source: author's own elaboration.

Table 5 provided a correlation matrix for the dependent variable ROA - along with independent and control variables used for the analysis - while Table 6 presented the correlation matrix for the models built with the dependent variable ROS. According 
to these two tables, there was almost no correlation between the share of foreign ownership FOROWNER and the firm performance indicator ROA, while showing a slightly negative correlation to ROS. Moreover, the correlation matrix revealed that there was a positive associative relationship between foreign ownership concentration FOROWNER and the share of international experts EXPERTS, which also confirmed hypothesis H2.

Table 5. Correlation matrix - ROA

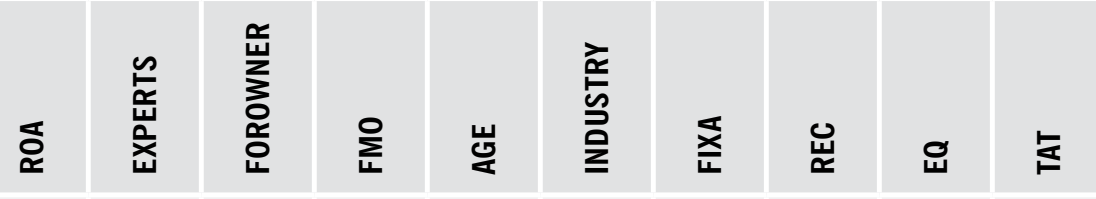

\begin{tabular}{|c|c|c|c|c|c|c|c|c|c|c|}
\hline ROA & 1.0000 & & & & & & & & & \\
\hline EXPERTS & 0.0205 & 1.0000 & & & & & & & & \\
\hline FOROWNER & -0.0057 & 0.3241 & 1.0000 & & & & & & & \\
\hline FMO & 0.1228 & 0.1458 & 0.0504 & 1.0000 & & & & & & \\
\hline AGE & 0.0446 & 0.0898 & 0.0671 & 0.0627 & 1.0000 & & & & & \\
\hline INDUSTRY & 0.0087 & -0.0437 & 0.0954 & 0.0937 & 0.3284 & 1.0000 & & & & \\
\hline FIXA & -0.1154 & 0.1259 & 0.0273 & 0.0052 & 0.0238 & 0.1037 & 1.0000 & & & \\
\hline REC & 0.0646 & -0.1054 & -0.0455 & -0.0186 & -0.0172 & -0.2225 & -0.5984 & 1.0000 & & \\
\hline EQ & 0.2713 & -0.0786 & -0.0413 & -0.0186 & 0.0558 & 0.0099 & 0.1266 & -0.2577 & 1.0000 & \\
\hline TAT & 0.1124 & -0.0380 & -0.0652 & 0.0760 & 0.0035 & -0.0666 & -0.4399 & 0.4245 & -0.2730 & 1.0000 \\
\hline
\end{tabular}

Source: author's own elaboration.

As expected, the share of international experts EXPERTS in supervisory boards was positively correlated (14.6\%) to the dummy variable that indicated whether a firm operates on foreign markets FMO. This was consistent with the literature review, which provided the idea of international experts' appointments to SBs with the aim of the development of foreign operations. On the other hand, the variable that indicated firms operating on foreign markets FMO uncovered a weak positive association with ROS on the level of positive 5 percentage points. Moreover, the firms with the foreign market operations variable were even more correlated to ROA, revealing an association at the level of $12.3 \%$. This would suggest that the companies operating on foreign markets more effectively convert invested money into net income than they improve operating efficiency, notwithstanding the fact of obvious interdependence between the two dependent variables and the factors that can determine their growth or decline. 
A moderate correlation appeared between the control variables FIXA and REC, but the level of correlation was within the suggested range, and variables could still be used simultaneously in one model.

Table 6. Correlation matrix - ROS

\begin{tabular}{|c|c|c|c|c|c|c|c|c|c|c|}
\hline & జ̊ & 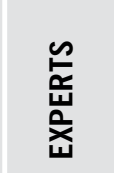 & 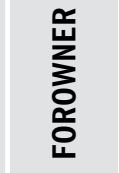 & $\sum_{i}^{\circ}$ & 岕 & $\begin{array}{l}\text { ¿ } \\
\text { 足 } \\
\text { 号 } \\
\underline{z}\end{array}$ & 흔 & 岀 & 욥 & 占 \\
\hline ROS & 1.0000 & & & & & & & & & \\
\hline EXPERTS & 0.0439 & 1.0000 & & & & & & & & \\
\hline FOROWNER & -0.0172 & 0.3241 & 1.0000 & & & & & & & \\
\hline FMO & 0.0503 & 0.1458 & 0.0504 & 1.0000 & & & & & & \\
\hline AGE & 0.0557 & 0.0898 & 0.0671 & 0.0627 & 1.0000 & & & & & \\
\hline INDUSTRY & 0.0204 & -0.0437 & 0.0954 & 0.0937 & 0.3284 & 1.0000 & & & & \\
\hline FIXA & -0.0249 & 0.1259 & 0.0273 & 0.0052 & 0.0238 & 0.1037 & 1.0000 & & & \\
\hline REC & 0.0894 & -0.1054 & -0.0455 & -0.0186 & -0.0172 & -0.2225 & -0.5984 & 1.0000 & & \\
\hline EQ & -0.0098 & -0.0786 & -0.0413 & -0.0186 & 0.0558 & 0.0099 & 0.1266 & -0.2577 & 1.0000 & \\
\hline TAT & 0.0994 & -0.0380 & -0.0652 & 0.0760 & 0.0035 & -0.0666 & -0.4399 & 0.4245 & -0.2730 & 1.0000 \\
\hline
\end{tabular}

Source: author's own elaboration.

The findings of the study clearly showed that the presence of investigated firms in foreign markets positively affected company performance. Moreover, both models with dependent variables ROA and ROS, uncovered that SB members with foreign experience positively affected profitability indicators of firms not present on foreign markets. This fact could be explained by the fact that listed companies on WSE engaged international supervisors with knowledge about specific foreign market conditions and tried to send a signal to the market about huge internationalization plans (Oxelheim and Randøy, 2003). Consequently, internationalization or the process of seeking new business horizons could have been implemented by involving international experts or foreign shareholders. 
Table 7. Empirical relationship between international expert share and firm contemporaneous ROA

\begin{tabular}{|c|c|c|c|}
\hline Subsample & Entire Sample & $\begin{array}{c}\text { Present } \\
\text { on Foreign Markets }\end{array}$ & $\begin{array}{c}\text { Not Present } \\
\text { on Foreign Markets }\end{array}$ \\
\hline \multirow{2}{*}{ Explained variable } & ROA & ROA & ROA \\
\hline & (1) & (2) & (3) \\
\hline \multirow{2}{*}{ AGE } & 0.003 & 0.005 & -0.002 \\
\hline & $(0.46)$ & $(0.62)$ & $(-0.20)$ \\
\hline \multirow{2}{*}{ FIXA } & $-0.043 * * *$ & $-0.077 * * *$ & -0.022 \\
\hline & $(-3.18)$ & $(-3.00)$ & $(-1.40)$ \\
\hline \multirow{2}{*}{ REC } & 0.010 & 0.002 & 0.024 \\
\hline & $(0.52)$ & $(0.06)$ & $(1.05)$ \\
\hline \multirow{2}{*}{$\mathrm{EQ}$} & $0.140 * * *$ & $0.125^{* * *}$ & $0.150 * * *$ \\
\hline & (11.29) & $(6.40)$ & $(9.49)$ \\
\hline \multirow{2}{*}{ TAT } & $0.012^{* * *}$ & $0.014 * *$ & $0.013^{* * *}$ \\
\hline & $(3.71)$ & $(2.42)$ & $(3.09)$ \\
\hline \multirow{2}{*}{ FMO } & $0.016 * * *$ & & \\
\hline & $(2.93)$ & & \\
\hline \multirow{2}{*}{ EXPERT } & & -0.003 & $0.038 * * *$ \\
\hline & & $(-0.19)$ & $(2.72)$ \\
\hline \multirow{2}{*}{ Constant } & $-0.037 * *$ & 0.007 & $-0.060 * * *$ \\
\hline & $(-2.42)$ & $(0.26)$ & $(-3.14)$ \\
\hline Industry dummies & Yes & Yes & Yes \\
\hline Year dummies & Yes & Yes & Yes \\
\hline R-squared & 0.140 & 0.210 & 0.126 \\
\hline Observations & 1536 & 554 & 982 \\
\hline
\end{tabular}

Note: the table presents a static panel GLS regression model with a random effect. The explained variable is contemporaneous firm-level financial performance measured by ROA. T-statistics are presented beneath respective regression coefficients. Statistical significance at $1 \%, 5 \%$ and $10 \%$ levels are denoted with $* * *, * *$ and * respectively. All models include time and industry fixed effects. All models include firm-level control variables. Joint statistical significance of models is measured with Wald statistic.

Source: author's own elaboration. 
According to Table 7, firms that operated on foreign markets had better financial performance (ROA), which was supported with a $1 \%$ statistical significance level. With that in mind, we built the two models to compare the effect of international experts on firm performance indicators in companies that operate on foreign markets and those that do not. The results suggested that firms without foreign markets operations have a higher level of ROA, while international experts tended to perform better when employed in such companies. The outcomes were supported by a $1 \%$ statistical significance level, which suggested that an increase in $1 \%$ of the international expert share could enhance the return on assets performance indicator by almost $4 \%$.

Table 8. Empirical relationship between international expert share and firm contemporaneous ROS

\begin{tabular}{|c|c|c|c|}
\hline Subsample & Entire Sample & $\begin{array}{c}\text { Present } \\
\text { on Foreign Markets }\end{array}$ & $\begin{array}{c}\text { Not Present } \\
\text { on Foreign Markets }\end{array}$ \\
\hline \multirow{2}{*}{ Explained variable } & ROS & ROS & ROS \\
\hline & (1) & (2) & (3) \\
\hline \multirow{2}{*}{ AGE } & 0.110 & 0.083 & 0.078 \\
\hline & $(1.31)$ & $(1.36)$ & $(0.63)$ \\
\hline \multirow{2}{*}{ FIXA } & 0.284 & -0.349 & 0.428 \\
\hline & $(1.36)$ & $(-1.53)$ & $(1.56)$ \\
\hline \multirow{2}{*}{ REC } & $0.720 * *$ & -0.095 & $1.135^{* * *}$ \\
\hline & $(2.55)$ & $(-0.35)$ & $(2.92)$ \\
\hline \multirow{2}{*}{ EQ } & $0.320 *$ & 0.251 & 0.438 \\
\hline & (1.65) & $(1.56)$ & $(1.61)$ \\
\hline \multirow{2}{*}{ TAT } & $0.123^{* *}$ & 0.047 & $0.148 * *$ \\
\hline & $(2.44)$ & $(1.04)$ & $(2.14)$ \\
\hline \multirow{2}{*}{ FMO } & 0.098 & & \\
\hline & (1.25) & & \\
\hline \multirow{2}{*}{ EXPERT } & & -0.117 & $0.595 * *$ \\
\hline & & $(-1.12)$ & $(2.51)$ \\
\hline \multirow{2}{*}{ Constant } & $-0.709 * * *$ & 0.220 & $-1.121^{* * *}$ \\
\hline & $(-3.01)$ & $(0.94)$ & $(-3.42)$ \\
\hline Industry dummies & Yes & Yes & Yes \\
\hline
\end{tabular}




\begin{tabular}{|l|c|c|c|}
\hline Year dummies & Yes & Yes & Yes \\
\hline R-squared & 0.025 & 0.033 & 0.041 \\
\hline Observations & 1536 & 554 & 982 \\
\hline
\end{tabular}

Note: the table presents a static panel GLS regression model with a random effect. The explained variable is contemporaneous firm-level operating performance measured by ROS. T-statistics are presented beneath respective regression coefficients. Statistical significance at $1 \%, 5 \%$ and $10 \%$ levels are denoted with $* * *$, ** and * respectively. All models include time and industry fixed effects. All models include firm-level control variables. Joint statistical significance of models is measured with Wald statistic.

Source: author's own elaboration.

From another perspective, Table 8 presented the results that indicate ROS is not significantly affected by the fact of firm operations on the foreign market. However, a similar impact of the regression coefficient share of international experts on financial performance was observed with $5 \%$ statistical significance. The magnitude of the coefficient suggested a strong positive effect on return on sales. Consequently, the findings did not support hypothesis H1, as they revealed that international experts are more effective advisors for the companies that during the observed period did not conduct business activities on foreign markets.

Table 9. Empirical relationship between foreign ownership and firm contemporaneous ROA \& ROS

\begin{tabular}{|c|c|c|}
\hline \multirow{2}{*}{ Explained Variables } & ROA & ROS \\
\hline & (1) & (2) \\
\hline \multirow{2}{*}{ AGE } & 0.001 & 0.142 \\
\hline & $(0.23)$ & $(0.57)$ \\
\hline \multirow{2}{*}{ FIXA } & $-0.083^{* *}$ & $-0.705^{*}$ \\
\hline & $(-2.05)$ & $(-1.94)$ \\
\hline \multirow{2}{*}{ REC } & -0.018 & 0.359 \\
\hline & $(-0.44)$ & $(0.71)$ \\
\hline \multirow{2}{*}{$\mathrm{EQ}$} & $0.175^{* * *}$ & $0.816 * *$ \\
\hline & $(6.54)$ & $(2.50)$ \\
\hline \multirow{2}{*}{ TAT } & 0.007 & $0.193 * *$ \\
\hline & $(0.87)$ & $(2.00)$ \\
\hline \multirow{2}{*}{ FOROWNER } & $0.080 * *$ & $0.995 *$ \\
\hline & (2.03) & (1.72) \\
\hline
\end{tabular}




\begin{tabular}{|l|c|c|}
\hline Constant & -0.025 & -0.473 \\
\hline Year dummies & $(-1.24)$ & $(-1.31)$ \\
\hline R-squared & Yes & Yes \\
\hline Observations & 0.097 & 0.006 \\
\hline
\end{tabular}

Note: the table presents a static panel GLS regression model with a fixed effect. The explained variable is contemporaneous firm-level financial and operating performance, measured by ROA and ROS. T-statistics are presented beneath respective regression coefficients. Statistical significance at $1 \%, 5 \%$ and $10 \%$ levels are denoted with $* * *$, $* *$ and * respectively. All models include time fixed effects. All models include firm-level control variables. Joint statistical significance of models is measured with Wald statistic.

Source: author's own elaboration.

Table 9 refers to whether foreign ownership enhanced firm performance. As shown in models, there was a positive impact of foreign shareholders on return on assets (ROA) and return on sales (ROS). The obtained results supported the positive impact of FOROWNER of ROA by $5 \%$ and of ROS by $10 \%$ statistical significance level, respectively. The presented models confirmed hypothesis H3, which stated that foreign ownership enhances firm financial and operating performance.

\section{Robustness Check}

To check the robustness of the GLS estimator with random effect model results, the dynamic two-step generalized method of moments was employed (GMM) (Arellano and Bond, 1991; Blundell and Bond, 1998). The GMM estimator can eliminate potential endogeneity issues, identifiable between unobservable heterogeneity and variables (Wintoki et al., 2012).

Table 10. Dynamic panel analysis of empirical relationship between international expert share and firm contemporaneous ROA

\begin{tabular}{|c|c|c|c|}
\hline Subsample & Entire Sample & $\begin{array}{c}\text { Present } \\
\text { on Foreign Markets }\end{array}$ & $\begin{array}{c}\text { Not Present } \\
\text { on Foreign Markets }\end{array}$ \\
\hline Explained variable & ROA & ROA & ROA \\
\hline L.ROA & $\mathbf{( 1 )}$ & $\mathbf{( 2 )}$ & $\mathbf{( 3 )}$ \\
\hline & $0.161^{\star}$ & $0.265^{\star * *}$ & 0.124 \\
\hline & $(1.78)$ & $(2.59)$ & $(1.14)$ \\
\hline
\end{tabular}




\begin{tabular}{|c|c|c|c|}
\hline \multirow{2}{*}{ AGE } & 0.002 & 0.010 & -0.005 \\
\hline & $(0.41)$ & $(1.62)$ & $(-0.73)$ \\
\hline \multirow{2}{*}{ FIXA } & -0.034 & $-0.068 * *$ & -0.018 \\
\hline & $(-1.59)$ & $(-2.40)$ & $(-0.70)$ \\
\hline \multirow{2}{*}{ REC } & 0.20 & 0.001 & 0.039 \\
\hline & $(0.85)$ & $(0.02)$ & $(1.29)$ \\
\hline \multirow{2}{*}{ EQ } & $0.137 * * *$ & $0.112 * * *$ & $0.155^{* * *}$ \\
\hline & $(6.81)$ & $(4.85)$ & $(6.44)$ \\
\hline \multirow{2}{*}{ TAT } & $0.012 * * *$ & $0.012^{*}$ & $0.012 * *$ \\
\hline & $(2.80)$ & $(1.77)$ & (2.09) \\
\hline \multirow{2}{*}{ FMO } & $0.016 * * *$ & & \\
\hline & $(3.10)$ & & \\
\hline \multirow{2}{*}{ EXPERTS } & & -0.014 & $0.045^{* * *}$ \\
\hline & & $(-1.42)$ & $(2.82)$ \\
\hline \multirow{2}{*}{ Constant } & 0.000 & 0.000 & 0.000 \\
\hline & (.) & (.) & (.) \\
\hline Industry Dummies & Yes & Yes & Yes \\
\hline Year Dummies & Yes & Yes & Yes \\
\hline ar1 & $-5.830 * *$ & $-2.590 * * *$ & $-4.940 * *$ \\
\hline ar2 & 1.340 & 0.120 & 1.28 \\
\hline Observations & 1280 & 464 & 816 \\
\hline
\end{tabular}

Note: The table summarizes the estimates of dynamic two-step GMM panel regression analysis. T-statistics are presented beneath respective regression coefficients. Statistical significance at $1 \%, 5 \%$ and $10 \%$ levels are denoted with $* * *, * *$ and * respectively. All models include time and industry-fixed effects which are not reported for reasons of brevity. All models include firm-level control variables. Arellano-Bond (1991) statistics AR(1) and AR(2) are reported for each analyzed model. The explained variable is ROA.

Source: author's own elaboration.

In Tables 10, 11, and 12 the dynamic panel analysis of the empirical relationship between the share of international experts on firms with foreign operations - along with the share of foreign ownership and ROA - were tested by adding a lagged dependent variable into the study's regression model so as to keep the influence of the previous period (year) financial performance indicators (ROA, ROS) on the current period (year). 
Table 11. Dynamic panel analysis of empirical relationship between international expert share and firm contemporaneous ROS

\begin{tabular}{|c|c|c|c|}
\hline Subsample & Entire Sample & $\begin{array}{c}\text { Present on Foreign } \\
\text { Markets }\end{array}$ & $\begin{array}{c}\text { Not Present on Foreign } \\
\text { Markets }\end{array}$ \\
\hline \multirow{2}{*}{ Explained variable } & ROS & ROS & ROS \\
\hline & (1) & (2) & (3) \\
\hline \multirow{2}{*}{ L.ROA } & 0.100 & $0.641^{* * *}$ & -0.076 \\
\hline & $(0.47)$ & $(5.07)$ & $(-0.35)$ \\
\hline \multirow{2}{*}{ AGE } & 0.100 & 0.010 & 0.082 \\
\hline & $(1.60)$ & $(0.41)$ & $(1.00)$ \\
\hline \multirow{2}{*}{ FIXA } & -0.043 & 0.233 & -0.017 \\
\hline & $(-0.10)$ & $(1.20)$ & $(-0.29)$ \\
\hline \multirow{2}{*}{ REC } & 0.226 & 0.005 & 0.383 \\
\hline & $(0.65)$ & $(0.05)$ & $(0.81)$ \\
\hline \multirow{2}{*}{ EQ } & 0.395 & $0.269 * *$ & 0.386 \\
\hline & $(1.64)$ & $(2.50)$ & $(1.03)$ \\
\hline \multirow{2}{*}{ TAT } & $0.094 * *$ & 0.047 & 0.088 \\
\hline & $(1.96)$ & $(1.44)$ & $(1.38)$ \\
\hline \multirow{2}{*}{ FMO } & 0.054 & & \\
\hline & $(0.88)$ & & \\
\hline \multirow{2}{*}{ EXPERTS } & & -0.051 & $0.523 * *$ \\
\hline & & $(-0.97)$ & $(2.08)$ \\
\hline \multirow{2}{*}{ Constant } & 0.000 & $-0.300 *$ & 0.234 \\
\hline & (.) & $(-1.67)$ & $(-0.69)$ \\
\hline Industry Dummies & Yes & Yes & Yes \\
\hline Year Dummies & Yes & Yes & Yes \\
\hline ar1 & $-2.240 * *$ & -0.510 & $-2.160 * *$ \\
\hline ar2 & 1.02 & -0.900 & 0.940 \\
\hline Observations & 1280 & 464 & 816 \\
\hline
\end{tabular}

Note: The table summarizes the estimates of dynamic two-step GMM panel regression analysis. T-statistics are presented beneath respective regression coefficients. Statistical significance at $1 \%, 5 \%$ and $10 \%$ levels are denoted with $* * *, * *$ and * respectively. All models include time and industry-fixed effects which are not reported for reasons of brevity. All models include firm-level control variables. Arellano-Bond (1991) statistics AR(1) and AR(2) are reported for each analyzed model. The explained variable is ROS.

Source: author's own elaboration. 
Table 12. Dynamic panel analysis of empirical relationship foreign ownership share and firm contemporaneous ROA \& ROS

\begin{tabular}{|c|c|c|}
\hline \multirow{2}{*}{ Explained variables } & ROA & ROS \\
\hline & (1) & (2) \\
\hline \multirow{2}{*}{ L.ROA } & $0.163^{*}$ & \\
\hline & $(1.80)$ & \\
\hline \multirow{2}{*}{ L.ROS } & & 0.099 \\
\hline & & $(0.46)$ \\
\hline \multirow{2}{*}{ AGE } & 0.002 & 0.102 \\
\hline & $(0.44)$ & $(1.83)$ \\
\hline \multirow{2}{*}{ FIXA } & -0.032 & -0.076 \\
\hline & $(-1.55)$ & $(-0.18)$ \\
\hline \multirow{2}{*}{ REC } & 0.021 & 0.198 \\
\hline & $(0.90)$ & $(0.66)$ \\
\hline \multirow{2}{*}{ EQ } & $0.140 * * *$ & 0.370 \\
\hline & $(7.04)$ & $(1.60)$ \\
\hline \multirow{2}{*}{ TAT } & $0.011^{* * *}$ & $0.098^{*}$ \\
\hline & $(2.78)$ & $(1.90)$ \\
\hline \multirow{2}{*}{ FOROWNER } & 0.001 & -0.214 \\
\hline & $(0.10)$ & $(-1.25)$ \\
\hline \multirow{2}{*}{ Constant } & 0.000 & 0.000 \\
\hline & (.) & (.) \\
\hline Year Dummies & Yes & Yes \\
\hline ar1 & $-5.850 * * *$ & $-2.220 * *$ \\
\hline ar2 & 1.370 & 1.010 \\
\hline Observations & 1280 & 1280 \\
\hline
\end{tabular}

Note: The table summarizes the estimates of dynamic two-step GMM panel regression analysis. T-statistics are presented beneath respective regression coefficients. Statistical significance at $1 \%, 5 \%$ and $10 \%$ levels are denoted with $* * *, * *$ and * respectively. All models include time and industry-fixed effects which are not reported for reasons of brevity. All models include firm-level control variables. Arellano-Bond (1991) statistics AR(1) and AR(2) are reported for each analyzed model. The explained variables are ROA and ROS.

Source: author's own elaboration. 
Table 13. The comparison of the static GLS regression model with a fixed or random effect \& dynamic GMM panel regression model results

\begin{tabular}{|c|c|c|c|c|c|c|c|c|}
\hline \multirow[b]{2}{*}{$\frac{\text { d }}{\frac{0}{\sigma}}$} & \multirow{2}{*}{ 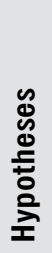 } & \multirow[b]{2}{*}{$\begin{array}{l}\frac{\omega}{d} \\
\frac{0}{0} \\
\frac{0}{\Sigma}\end{array}$} & \multirow{2}{*}{ 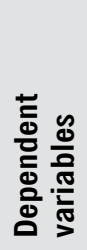 } & \multirow{2}{*}{ 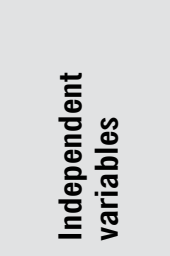 } & $\begin{array}{l}\text { Sign } \\
(+/-)\end{array}$ & $\begin{array}{c}\text { GLS regression } \\
\text { model with } \\
\text { a fixed/random } \\
\text { effect }\end{array}$ & $\begin{array}{l}\text { Sign } \\
(+/-)\end{array}$ & $\begin{array}{l}\text { GMM } \\
\text { regression } \\
\text { model }\end{array}$ \\
\hline & & & & & \multicolumn{4}{|c|}{$\begin{array}{c}\text { Statistical significance at } 1 \%, 5 \% \\
\text { and } 10 \% \text { levels or "non-significance" }\end{array}$} \\
\hline \multirow{3}{*}{4,7} & \multirow{6}{*}{1} & 1 & \multirow{3}{*}{ ROA } & FMO & + & $1 \%$ & + & $1 \%$ \\
\hline & & \begin{tabular}{l}
\multicolumn{1}{c}{2} \\
(Firms Present \\
on Foreign \\
Markets)
\end{tabular} & & EXPERTS & - & $\begin{array}{l}\text { Non- } \\
\text { significance }\end{array}$ & - & $\begin{array}{l}\text { Non- } \\
\text { significance }\end{array}$ \\
\hline & & $\begin{array}{l}\quad 3 \\
\text { (Firms } \\
\text { Not Present } \\
\text { on Foreign } \\
\text { Markets) }\end{array}$ & & EXPERTS & + & $1 \%$ & + & $1 \%$ \\
\hline \multirow{3}{*}{5,8} & & 1 & \multirow{3}{*}{ ROS } & FMO & + & $\begin{array}{l}\text { Non- } \\
\text { significance }\end{array}$ & + & $\begin{array}{l}\text { Non- } \\
\text { significance }\end{array}$ \\
\hline & & \begin{tabular}{l}
\multicolumn{1}{c}{2} \\
(Firms Present \\
on Foreign \\
Markets)
\end{tabular} & & EXPERTS & - & $\begin{array}{l}\text { Non- } \\
\text { significance }\end{array}$ & - & $\begin{array}{l}\text { Non- } \\
\text { significance }\end{array}$ \\
\hline & & \begin{tabular}{l}
$\quad 3$ \\
\multicolumn{1}{c}{ (Firms } \\
Not Present \\
on Foreign \\
Markets)
\end{tabular} & & EXPERTS & + & $5 \%$ & + & $5 \%$ \\
\hline \multirow{2}{*}{6,9} & \multirow{2}{*}{3} & 1 & ROA & FOROWNER & + & $5 \%$ & + & $\begin{array}{l}\text { Non- } \\
\text { significance }\end{array}$ \\
\hline & & 2 & ROS & FOROWNER & + & $10 \%$ & - & $\begin{array}{l}\text { Non- } \\
\text { significance }\end{array}$ \\
\hline
\end{tabular}

Source: author's own elaboration.

The summary of the robustness check presented in Table 13 showed that the findings were similar to those previously performed by implementing a GLS estimator with a random effect, which supported the developed hypotheses. The difference was identified only in the empirical relationship between foreign ownership and firm contemporaneous ROA and ROS in GLS estimator with a fixed effect. 


\section{Discussion and Conclusions}

In the world of increasing globalization, one of the most important changes is the increasing strength of competition among countries. The tough calls that firms face may be the reduction of profit margins and truly fast innovation changes that force companies to continually cut costs and implement adjustments to strategic decisions so that they could survive on the market. The fairly intensive international competition raises the question about the quality of corporate governance that should be adjusted to today's challenges. Undoubtedly, countries like Poland must compete for foreign investors from other established markets while developing foreign operations, which is the survival kit of the globalized world.

Moreover, the internationalization trend affects the SBs of companies listed on the WSE. The interest in having international representatives in SBs of listed entities significantly increases, motivated by the idea that foreign experts lead to company internationalization. Consequently, determinants of company success on foreign markets are interesting objects of study as they were not elaborately studied on the two-tier corporate governance model.

This study identified the incorporation of foreign experts and home-country-based experts with international experience to SBs as one of the key elements of corporate governance adaptation to the internationalization of firm operations. For the study, a comprehensive panel dataset with a sample that consisted of 356 companies listed on the WSE in 2010-2015 was built. The raw database was reduced to 257 firms with 1542 reviewed annual reports compiled from official investor relations sections of corporate websites. For the investigation, three explanatory variables were employed as proxies for firm internationalization, namely (1) the share of international experts in supervisory boards of directors (EXPERTS); (2) the percentage of ordinary shares held by foreign investors (FOROWNER); and (3) a dummy variable FMO that indicated the company operating on foreign markets. The two firm performance indicators (ROA and ROS) were used as dependent variables.

The first independent variable used in the empirical analysis was built to evaluate the effect of foreign experience of SB members EXPERTS in companies that operate abroad on the effectiveness of advisory role performance. The second explanatory variable was the dummy variable FMO that indicated the company operating on foreign markets was developed to check whether the international experts are more effective advisors for the companies that operate in foreign markets. 
The research models revealed that with the increase in the share of international experts in SBs, the financial performance of companies absent from foreign markets improves, as they obtain higher effects in return on sales. This suggests that international experts may bring a new perspective on strategic decisions related to sales channels, but only for companies with domiciled operations. The results did not support the expectations expressed in hypothesis H1. We may explain this following Sanders and Carpenter (1998), who suggest that the operation internationalization can create information asymmetry issues between SBs and managers, which then results in higher monitoring costs. The authors argue that international operations increase managerial complexity and environmental uncertainty, which in turn are associated with information processing demands. Developing on that idea, it concludes that the division of the effects caused by the performance of different roles is hardly possible, while analyses fail to investigate the advisory role separately. Consequently, the current study effects could have been affected by the negative impact of high monitoring costs, which could overperform the positive impact of advisory role performance.

Therefore, international experts can indeed be a source of valuable knowledge about employees with international experience, foreign suppliers, and customers, along with foreign networks, which can jointly help in gaining important network ties (Ramaswamy, 2001; Barroso et al., 2011; Afzali et al., 2020). However, the current research results failed to support this hypothesis (H1).

The third independent variable was the percentage of ordinary shares held by foreign investors (FOROWNER), which was to test another hypothesis stating that there is a positive associative relationship between foreign ownership concentration and the share of international experts (H2). The findings confirmed a positive moderate association between the two variables. Moreover, the results revealed that the higher the share of foreign ownership, the better the financial and operating performance of the company.

Therefore, the research contributes to the development of Polish corporate governance and, consequently, the increase in management and supervision efficiency. The results can be used to develop corporate governance guidelines and arguments for the inclusion of international experts as an aspect that diversifies SBs; these elements can also be added to the best practices of WSE-listed companies (WSE, 2016).

Nevertheless, this article has certain limitations. First, the study was based on a period after a crisis and preceding a time when the Polish market started to be classified as a developed market. The analysis of a longer period could open a broader view of the 
impact of international experts on company internationalization. Second, the presented research was limited to the Polish context, thus omitting other institutional environments. Third, the investigation of the general effect of international experts' presence was considered without personal and group characteristics, such as gender diversity, independence, financial experience, education, and domestic/foreign interlocks, which could bring more insight to the understanding of obtained effects' drivers. Further studies can develop the abovementioned aspects.

\section{References}

Abdeljawad, I., and Masri, R.M. (2020). Board Characteristics and Corporate Performance: Evidence From Palestine. An-Najah University Journal for Research-B (Humanities), 34(4).

Abdullah, S.N. (2014). Board composition, CEO duality and performance among Malaysian listed Companies. Corporate Governance International Journal of Business in Society, 4(1), 47-61. https://doi.org/10.1108/14720700410558871.

Abu, S.O., Okpeh, A.J., and Okpe, U.J. (2016). Board characteristics and financial performance of deposit money banks in Nigeria. International Journal of Business and Social Science, 7(9), 1-13. https://doi.org/10.32861/jssr.52.418.423.

Adams, R.B., Hermalin, B.E., and Weisbach, M.S. (2010). The role of boards of directors in corporate governance: A conceptual framework and survey. Journal of Economic Literature, 48(1), 58-107. https://doi.org/10.1257/jel.48.1.58.

Adeusi, S.O., Akeke, N.I., and Aribaba, F.O. (2013). Corporate governance and firm financial performance: Do ownership and board size matter? Academic Journal of Interdisciplinary Studies, 2(3), 77-91. https://doi.org/10.5901/ajis.2013.v2n3p251.

Afzali, H., Martikainen, M., Oxelheim, L., and Randøy, T. (2020). On the Role of Internationalization of Firm-Level Corporate Governance-The Case of Audit Committees (No. 1370). IFN Working Paper. Obtained from: https://www.econstor.eu/bitstream/10419/240513/1/wp1370.pdf (access: 25.10.2021).

Amin, S.I.M. and Nor, S.M. (2019). Board diversity and firm performance in the construction, manufacturing, and trading/services industries. Asian Journal of Accounting and Governance, 12.

Arellano, M., and Bond, S. (1991). Some tests of specification for panel data: Monte Carlo evidence and an application to employment equations. The Review of Economic Studies, 58(2), 277-297. https://doi.org/10.2307/2297968.

Azutoru, I.H.C., Obinne, U.G., and Chinelo, O.O. (2017). Effect of corporate governance mechanisms on financial performance of insurance companies in Nigeria. Journal of Finance and Accounting, 5(3), 93-103. https://doi.org/10.5897/AJBM2019.8766.

Barroso, C., Villegas, M.M., and Pérez-Calero, L. (2011). Board influence on a firm's internationalization. Corporate Governance: An International Review, 19(4), 351-367. https://doi.org/10.1111/j.1467-8683.2011.00859.x.

Blundell, R., and Bond, S. (1998). Initial conditions and moment restrictions in dynamic panel data models. Journal of Econometrics, 87(1), 115-143. https://doi.org/10.1016/S0304-4076(98)00009-8.

Boadi, I. and Osarfo, D. (2019). Diversity and return: the impact of diversity of board member education on performance. Corporate Governance: The International Journal of Business in Society, 19(4), 824-842. 
Bradbury, M., Mak, Y.T., and Tan, S.M. (2006). Board characteristics, audit committee characteristics and abnormal accruals. Pacific Accounting Review, 18(2), 47-68. https://doi.org/10.1108/01140580610732813.

Breusch, T.S., and Pagan, A.R. (1979). A simple test for heteroscedasticity and random coefficient variation. Econometrica: Journal of the Econometric Society, 1287-1294. https://doi.org/10.2307/1911963.

Buzavaite, M., and Korsakiene, R. (2019). Human Capital and the Internationalisation of SMEs: A Systemic Literature Review. Entrepreneurial Business and Economics Review, 7(3), 125-142. https://doi.org/10.15678/EBER.2019.070307.

Calof, J.L., and Beamish, P.W. (1995). Adapting to foreign markets: Explaining internationalization. International Business Review, 4(2), 115-131. https://doi.org/10.1016/0969-5931(95)00001-G.

Chen, H.L., Chang, C.Y., and Hsu, W.T. (2017). Does board Co-working experience influence directors' decisions toward internationalization? Management International Review, 57(1), 65-92. https://doi.org/10.1007/s11575-016-0309-4.

Chizema, A., and Kim, J. (2010). Outside directors on Korean boards: Governance and institutions. Journal of Management Studies, 47(1), 109-129. https://doi.org/10.1111/j.1467-6486.2009.00868.x.

Choi, J.J., Park, S.W., and Yoo, S.S. (2007). The value of outside directors: Evidence from corporate governance reform in Korea. Journal of financial and Quantitative Analysis, 941-962. https://doi.org/10.1017/S0022109000003458.

Cook, R.D., and Weisberg, S. (1983). Diagnostics for heteroscedasticity in regression. Biometrika, 70(1), 1-10. https://doi.org/10.1093/biomet/70.1.1.

Cuervo, A. (2002). Corporate governance mechanisms: A plea for less code of good governance and more market control. Corporate Governance: An International Review, 10(2), 84-93. https://doi.org/10.1111/1467-8683.00272.

Dedunu, H. and Anuradha, P.A.N.S. (2020). Impact of Board Diversity on Firm Performance: Evidence from Sri Lanka. International Journal of Management, Innovation and Entrepreneurial Research, 6(1), 23-31. https://doi.org/10.18510/ijmier.2020.614.

Dobija, D., and Kravchenko, G. (2017). Supervisory board composition and firm financial performance: a case of companies listed on the Warsaw stock exchange. Journal of Management and Business Administration. Central Europe, 25(4), 75-95.

https://doi.org/10.7206/jmba.ce.2450-7814.208.

Dobija, D., and Puławska, K. (2021). The influence of board members with foreign experience on the timely delivery of financial reports. Journal of Management and Governance, 1-27. https://doi.org/10.1007/s10997-020-09559-1.

Duque-Grisales, E., Aguilera-Caracuel, J., Guerrero-Villegas, J., and García-Sánchez, E. (2020). Can proactive environmental strategy improve Multilatinas' level of internationalization? The moderating role of board independence. Business Strategy and the Environment, 29(1), 291-305. https://doi.org/10.1002/bse.2377.

Estélyi, K.S., and Nisar, T.M. (2016). Diverse boards: Why do firms get foreign nationals on their boards? Journal of Corporate Finance, 39, 174-192. https://doi.org/10.1016/j.jcorpfin.2016.02.006.

Fama, E.F., and Jensen, M.C. (1983). Separation of ownership and control. The Journal of Law and Economics, 26(2), 301-325. https://doi.org/10.2139/ssrn.94034.

Frijns, B., Dodd, O. and Cimerova, H. (2016). The impact of cultural diversity in corporate boards on firm performance. Journal of Corporate Finance, 41, 521-541.

https://doi.org/10.1016/j.jcorpfin.2016.07.014. 
García-Sánchez, I. M., and García-Meca, E. (2018). Do talented managers invest more efficiently? The moderating role of corporate governance mechanisms. Corporate Governance: An International Review, 26(4), 238-254. https://doi.org/10.1111/corg.12233.

Giannetti, M., Liao, G., and Yu, X. (2012). The brain gain of corporate boards: A natural experiment from China. London: Centre for Economic Policy Research. Obtained from: http://www.ivey. uwo.ca/cmsmedia/163791/-gly_the_brain_gain_of_corporate_boards_april_21_2012.pdf (access: 11.02.2021).

Giannetti, M., Liao, G., and Yu, X. (2015). The brain gain of corporate boards: Evidence from China. The Journal of Finance, 70(4), 1629-1682. https://doi.org/10.1111/jofi.12198.

Goergen, M., and Tonks, I. (2019). Introduction to Special Issue on Sustainable Corporate Governance. British Journal of Management, 30(1), 3-9. https://doi.org/10.1111/1467-8551.12325.

González, C. (2019). Transnational board interlocks: the influence of degree of internationalization and psychic distance. Cross Cultural \& Strategic Management, 10(4). https://doi.org/10.1108/JSMA-07-2016-0043.

Goodstein, J., Gautam, K., and Boeker, W. (1994). The effects of board size and diversity on strategic change. Strategic Management Journal, 15(3), 241-250. https://doi.org/10.1002/smj.4250150305.

Grosfeld, I., and Hashi, I. (2007). Changes in ownership concentration in mass privatised firms: Evidence from Poland and the Czech Republic. Corporate Governance: An International Review, 15(4), 520-534. https://doi.org/10.1111/j.1467-8683.2007.00585.x.

Guest, P.M. (2019). Does board ethnic diversity impact board monitoring outcomes? British Journal of Management, 30(1), 53-74. https://doi.org/10.1111/1467-8551.12299.

Gurbuz, A.O., and Aybars, A. (2010). The impact of foreign ownership on firm performance, evidence from an emerging market: Turkey. American Journal of Economics and Business Administration, 2(4), 350-359. https://doi.org/10.3844/ajebasp.2010.350.359.

Hambrick, D.C., Davison, S.C., Snell, S.A., and Snow, C.C. (1998). When groups consist of multiple nationalities: Towards a new understanding of the implications. Organization Studies, 19(2), 181-205. https://doi.org/10.1177/017084069801900202.

Hausman, J.A. (1978). Specification tests in econometrics. Econometrica: Journal of the Econometric Society, 46, 1251-1271. https://doi.org/10.2307/1913827.

Hillman, A.J., Withers, M.C., and Collins, B.J. (2009). Resource dependence theory: A review. Journal of management, 35(6), 1404-1427. https://doi.org/10.1177/0149206309343469.

Hooghiemstra, R., Hermes, N., Oxelheim, L., and Randøy, T. (2019). Strangers on the board: The impact of board internationalization on earnings management of Nordic firms. International Business Review, 28(1), 119-134. https://doi.org/10.1016/j.ibusrev.2018.08.007.

Hossain, B. (2020). Director remuneration and performance: Evidence from the textile sector of Bangladesh. Journal of Asian Finance, Economics and Business, 7(6), 265-275. https://doi.org/10.13106/jafeb.2020.vol7.no6.265.

Imade, O.G. (2019). Board gender diversity, non-executive directors composition and corporate performance: evidence from listed firms in Nigeria. African Journal of Business Management, 13(9), 283-290. https://doi.org/10.5897/AJBM2019.8766.

Isidro, H. and Sobral, M. (2014). The effects of women on corporate boards on firm value, financial performance, and ethical and social compliance. Journal of Business Ethics, 132(1), 1-19. https://doi.org/10.1007/s10551-014-2302-9.

Jackowicz, K., Kozłowski, Ł., and Mielcarz, P. (2014). Political connections and operational performance of non-financial firms: New evidence from Poland. Emerging Markets Review, 20, 109-135. https://doi.org/10.1016/j.ememar.2014.06.005. 
Jakpar, S., Tinggi, M., Johari, A., and Myint, K.T. (2019). Analysis of Corporate Governance and Firm Performance: Evidence from Malaysian Listed Companies. International Journal of Business and Social Science, 10(1), 118-133. https://doi.org/10.30845/ijbss.v10n1p14.

Jentsch, V. (2019). Board Composition, Ownership Structure and Firm Value: Empirical Evidence from Switzerland. European Business Organization Law Review, 20(2), 203-254. https://doi.org/10.1007/s40804-018-00128-6.

Joh, S.W., and Jung, J.Y. (2018). When do firms benefit from affiliated outside directors? Evidence from Korea. Corporate Governance: An International Review, 26(6), 397-413. https://doi.org/10.1111/corg.12224.

Kaczmarek, S., Kimino, S. and Pye, A. (2012). Antecedents of board composition: The role of nomination committees. Corporate Governance: An International Review, 20(5), 474-489. https://doi.org/10.1111/j.1467-8683.2012.00913.x.

Kim, Y., and Cannella Jr, A.A. (2008). Toward a social capital theory of director selection. Corporate Governance: An International Review, 16(4), 282-293. https://doi.org/10.1111/j.1467-8683.2008.00693.x.

Knežević, G., Pavlović, V. and Bojičić, R. (2017). Does the board gender diversity impact financial performance in agriculture? Case of Serbian Agriculture Companies listed on Stock Exchange. Custos e agronegocio on line, 13(3), 2-20.

Koładkiewicz, I. (2008). Praktyka polskich rad nadzorczych-z perspektywy jej zagranicznych członków. Organizacja, 100, 53-65.

Kumar, N., and Singh, J.P. (2013). Effect of board size and promoter ownership on firm value: some empirical findings from India. Corporate Governance: The International Journal of Business in Society, 13(1), 88-98. https://doi.org/10.1108/14720701311302431.

Kumar, P. and Zattoni, A. (2018). Corporate governance, boards of directors, and firm performance: Avenues for future research. Corporate Governance: An International Review, 26(6), 394-396. https://doi.org/10.1111/corg.12262.

Levin, D.Z., Whitener, E.M., and Cross, R. (2006). Perceived trustworthiness of knowledge sources: The moderating impact of relationship length. Journal of Applied Psychology, 91(5), 1163. https://doi.org/10.1037/0021-9010.91.5.1163.

Luo, Y. (2005). How does globalization affect corporate governance and accountability? A perspective from MNEs. Journal of International Management, 11(1), 19-41. https://doi.org/10.1016/j.intman.2004.11.003.

Mangena, M., and Tauringana, V. (2007). Disclosure, corporate governance and foreign share ownership on the Zimbabwe stock exchange. Journal of International Financial Management and Accounting, 18(2), 53-85. https://doi.org/10.1111/j.1467-646X.2007.01008.x.

Masulis, R.W., Wang, C. and Xie, F. (2012). Globalizing the boardroom - The effects of foreign directors on corporate governance and firm performance. Journal of Accounting and Economics, 53(3), 527-554. https://doi.org/10.1016/j.jacceco.2011.12.003.

Mehmood, R., Hunjra, A.I. and Chani, M.I. (2019). The impact of corporate diversification and financial structure on firm performance: evidence from South Asian countries. Journal of Risk and Financial Management, 12(1), 49. https://doi.org/10.3390/jrfm12010049.

Mirza, N.I., Malik, Q.A. and Mahmood, C.K. (2020). The value of board diversity in the relationship of corporate governance and investment decisions of Pakistani firms. Journal of Open Innovation: Technology, Market, and Complexity, 6(4), 146. https://doi.org/10.3390/joitmc6040146.

Mortimer, T. (2009). Corporate governance in Poland. Corporate Ownership and Control, 7(2), 382-389.

Munisi, G., Hermes, N., and Randøy, T. (2014). Corporate boards and ownership structure: Evidence from Sub-Saharan Africa. International Business Review, 23(4), 785-796.

https://doi.org/10.1016/j.ibusrev.2013.12.001. 
Ngo, Q.H. (2021). The impact of market orientation on small businesses' performance in Vietnam: The mediating effects of the management accounting system. Entrepreneurial Business and Economics Review, 9(3), 59-72. https://doi.org/10.15678/EBER.2021.090304.

Nielsen, B.B., and Nielsen, S. (2013). Top management team nationality diversity and firm performance: A multilevel study. Strategic Management Journal, 34(3), 373-382. https://doi.org/10.1002/smj.2021.

Oxelheim, L., and Randøy, T. (2003). The impact of foreign board membership on firm value. Journal of Banking \& Finance, 27(12), 2369-2392. https://doi.org/10.1016/S0378-4266(02)00395-3.

Oxelheim, L., and Randøy, T. (2013). Globalization of monitoring practices: The case of American influences on the dismissal risk of European CEOs. Journal of Economics and Business, 70, 3-15. https://doi.org/10.1016/j.jeconbus.2013.02.002.

Park, Y.W., and Shin, H.H. (2004). Board composition and earnings management in Canada. Journal of Corporate Finance, 10(3), 431-457.

Peasnell, K.V., Pope, P.F., and Young, S. (2005). Board monitoring and earnings management: do outside directors influence abnormal accruals? Journal of Business Finance \& Accounting, 32(7-8), 1311-1346. https://doi.org/10.1111/j.0306-686X.2005.00630.x.

Peij, S.C., Bezemer, P.J., and Maassen, G.F. (2012). The effectiveness of supervisory boards: an exploratory study of challenges in Dutch boardrooms. International Journal of Business Governance and Ethics, 7(3), 191-208. https://doi.org/10.1504/IJBGE.2012.050041.

Puławska, K., Dobija, D., Piotrowska, K., and Kravchenko, G. (2021). Audit Committee Formation: The Case of Poland1. Journal of Management and Business Administration. Central Europe, 29(2), 169-212. https://doi.org/10.7206/cemj.2658-0845.50.

Ramaswamy, K., and Li, M. (2001). Foreign investors, foreign directors and corporate diversification: an empirical examination of large manufacturing companies in India. Asia Pacific Journal of Management, 18(2), 207-222. https://doi.org/10.1023/A:1010620008101.

Salehi, M., Sadatifar, Z. and Adibian, M.S. (2020). The impact of the characteristics and behaviors of the board of directors on agency costs in Iran. Contaduría y Administración, 66(1), 229. https://doi.org/10.22201/fca.24488410e.2021.2384.

Sanders, W.G., and Carpenter, M.A. (1998). Internationalization and firm governance: The roles of CEO compensation, top team composition, and board structure. Academy of Management journal, 41(2), 158-178. https://doi.org/10.2307/257100.

Shin, J.Y., Hyun, J.H., Oh, S., and Yang, H. (2018). The effects of politically connected outside directors on firm performance: Evidence from Korean chaebol firms. Corporate Governance: An International Review, 26(1), 23-44. https://doi.org/10.1111/corg.12203.

Słomka-Gołębiowska, A., and Urbanek, P. (2016). Corporate boards, large blockholders and executive compensation in banks: Evidence from Poland. Emerging Markets Review, 28, 203-220. https://doi.org/10.1016/j.ememar.2016.08.001.

Soliman, M. and Ragab, A.A. (2013). Board of director's attributes and earning management: Evidence from Egypt. Proceedings of 6th International Business and Social Sciences Research Conference.

Tapver, T. (2019). CSR reporting in banks: does the composition of the board of directors matter. Quant Financ Econ, 3(2), 286-314. https://doi.org/10.3934/QFE.2019.2.286.

Van Veen, K., and Elbertsen, J. (2008). Governance regimes and nationality diversity in corporate boards: A comparative study of Germany, the Netherlands and the United Kingdom. Corporate Governance: An International Review, 16(5), 386-399. https://doi.org/10.1111/j.1467-8683.2008.00698.x.

Wang, X., Feng, M., and Xu, X. (2019). Political connections of independent directors and firm internationalization: An empirical study of Chinese listed firms. Pacific-Basin Finance Journal, 58, 101205. https://doi.org/10.1016/j.pacfin.2019.101205. 
Watson, W.E., Kumar, K., and Michaelsen, L.K. (1993). Cultural diversity's impact on interaction process and performance: Comparing homogeneous and diverse task groups. Academy of Management Journal, 36(3), 590-602. https://doi.org/10.5465/256593.

Wiersema, M.F., and Bantel, K.A. (1992). Top management team demography and corporate strategic change. Academy of Management Journal, 35(1), 91-121. https://doi.org/10.5465/256474.

Wintoki, M.B., Linck, J.S., and Netter, J.M. (2012). Endogeneity and the dynamics of internal corporate governance. Journal of Financial Economics, 105(3), 581-606. https://doi.org/10.1016/j.jfineco.2012.03.005.

WSE, Best Practice for GPW Listed Companies 2016. Obtained from: https://www.gpw.pl/pub/GPW/o-nas/DPSN2016_EN.pdf (access: 25.04.2021).

Yarbrough Jr, E., Abebe, M., and Dadanlar, H. (2017). Board political experience and firm internationalization strategy: A resource dependence perspective. Journal of Strategy and Management, 10(2). https://doi.org/10.1108/JSMA-07-2016-0043.

Zainal, D., Zulkifli, N., and Saleh, Z. (2013). Corporate board diversity in Malaysia: A longitudinal analysis of gender and nationality diversity. International Journal of Academic Research in Accounting, Finance and Management Sciences, 3(1), 136-148. 